\title{
What Kind of School Organizational Decisions Serve to Enhance Sustainable Personal and Social Growth?
}

\author{
José Víctor Orón Semper ${ }^{1} \mathbb{D}$, Inmaculada Lizasoain ${ }^{2,3, * \mathbb{D}}$, Jaione Abaurrea ${ }^{2} \mathbb{D}$, Concepción González-García ${ }^{4} \mathbb{D}$ \\ and Esperanza Ayuga-Téllez 4 (D) \\ 1 Fundación UpToYou Educación, 50015 Zaragoza, Spain; jv.oron@uptoyoueducacion.com \\ 2 Department of Statisitics, Computer Sciences and Mathematics, Universidad Pública de Navarra, \\ Campus Arrosadia, 31006 Pamplona, Spain; jaione.abaurrea@unavarra.es \\ 3 Institute of Advanced Materials and Mathematics, INAMAT ${ }^{2}$, Universidad Pública de Navarra, \\ Campus Arrosadia, 31006 Pamplona, Spain \\ 4 Department of Forestry and Environmental Engineering and Management, Universidad Politécnica de \\ Madrid, 28040 Madrid, Spain; concepcion.gonzalez@upm.es (C.G.-G.); esperanza.ayuga@upm.es (E.A.-T.) \\ * Correspondence: ilizasoain@unavarra.es
}

Citation: Orón Semper, J.V.;

Lizasoain, I.; Abaurrea, J.;

González-García, C.; Ayuga-Téllez, E. What Kind of School Organizational Decisions Serve to Enhance Sustainable Personal and Social Growth? Sustainability 2021, 13, 9995. https://doi.org/10.3390/su13179995

Academic Editor: Yuzhuo Cai

Received: 14 July 2021

Accepted: 30 August 2021

Published: 6 September 2021

Publisher's Note: MDPI stays neutral with regard to jurisdictional claims in published maps and institutional affiliations.

Copyright: (c) 2021 by the authors. Licensee MDPI, Basel, Switzerland. This article is an open access article distributed under the terms and conditions of the Creative Commons Attribution (CC BY) license (https:// creativecommons.org/licenses/by/ $4.0 /)$.

\begin{abstract}
Sustainable decisions in education are those which pursue long-term achievements for students. In many cases, the principals of the schools are those who must make these decisions. In this paper we explore some of the factors that influence the students' long-term development by means of an analysis of the correlation between certain organizational aspects of the schools which directly depend on the principals and the scores that their students have obtained in the International Assessment PISA 2018 in mathematics, reading and science. The results point to a better long-term student achievement when the organizational decisions are designed to enhance interpersonal relationships (teacher-teacher, teacher-student and student-student), responding to the specific needs of each person and based on trust. Conversely, it seems that when the organizational decisions are merely made to control academic life, they either bear upon academic achievement in a negative way or do not significantly affect it. The results suggest that carefully attending to interpersonal relationships is the key factor behind all the educational decisions which generate sustainable socio-personal development.
\end{abstract}

Keywords: PISA results; school organizational decisions; sustainable development; interpersonal relationships

\section{Introduction}

The objectives outlined by the UN in the 2030 Agenda for Sustainable Development [1] have paved the way for the political decisions in education throughout the world over the coming decades. Sustainable decisions in education are those which seek to achieve long-term outcomes in students, and as such they are decisions which are not only taken by the political institutions but also by the principals of the schools.

Research literature has already demonstrated that school principals' actions cannot be separated from student outcomes, from academic achievement to social and emotional development [2]. Moreover, school principals are critical actors in encouraging teachers to be involved in professional evaluation processes and in fostering their professional development [3], which indirectly influences students' development. Jarl et al. [4] show that school performance is the result of human behavior and relationships. It can be affected and changed by the actions of individual teachers and principals as well as by policy-makers. The authors explain how success is fostered by an organizational dynamic that both encourages and reproduces cooperation and support among colleagues as well as a shared vision of teachers and principals acting on behalf of the learning of all students. In this regard, Intxausti et al. [5] consider the action of school leaderships as crucial in achieving effectiveness in education. 
A primary goal of this paper was to explore some of the factors that influence students' long-term development by means of an analysis of the statistical correlation between the organizational aspects of the schools which depend on the principal and the scores that they have obtained in the international assessments PISA 2018 (OECD's programme for International Student Assessment aimed to measure 15-year-olds' ability to use their reading, mathematics and science knowledge and skills to meet real-life challenges) of competence in mathematics, reading and science, as well as in global competence.

Global competence has been defined as the capacity to examine local, global and intercultural issues, to understand and appreciate the perspectives and world views of others, to engage in open, appropriate and effective interactions with people from different cultures, and to act for collective well-being and sustainable development [6]. The students' assessment in global competence in PISA 2018 was carried out by means of indicators of specific socio-emotional skills and attitudes towards global and intercultural issues, as well as by measuring some reasoning and argumentation skills related to these issues [7].

However, we have noticed that the answers to the students' PISA 2018 questionnaire about global competence have been significantly incomplete. Some participant schools have only partially completed them and others have not answered them at all. For this reason, we have decided not to include the students' assessments in global competence in our study. Even so, certain issues related to global competence have been considered in our study because, in the PISA 2018 school questionnaire addressed to the principals of the schools [8], they are asked about specific organizational aspects particularly relevant to global competence, such as the carrying out of practices related to multicultural learning in their school, the inclusion of some multicultural aspects in the formal curricula of their countries (communicating with people from different cultures, knowledge of these cultures, respect for cultural diversity, openness towards intercultural experiences, foreign languages, critical thinking skills, etc.) or the inclusion in the official curricula of topics such as climate change and global warming, global health, migration and international conflicts, hunger or malnutrition in different parts of the world, causes of poverty or equality between men and women in different parts of the world.

The questionnaire addressed to the school principals also includes questions about other issues related to the principals' way of understanding education, whether as a mere question of skills to be acquired $([9,10])$ or as a process which also includes personal and social development [11]; their perspectives on, for instance, how to approach the career guidance of their students, the use of digital devices of social networks in teaching, the criteria for grouping students into different classes (by ability or otherwise), how the assessments of students are used (to classify them into categories or to guide students' learning and adapt teaching to students' needs); the way that the school use the external or internal evaluations and so on.

The diverse perspectives of understanding education have been related by Orón et al. [12] to three models of understanding human development [13]: (1) the autonomous self model (AS), which conceives of human growth as driven by cognition, and achieved as a result of individual productive activity aimed at mastering the environment, according to the wishes of the individual; (2) the personal self model (PS), which also understands the action as driven by cognition, whilst also giving value to human relationships in the pursuit of individual growth; (3) the inter-processual self (IPS), a social model of human interpersonal development which considers that personal growth cannot occur without the individual attending to personal relationships, looking for others' growth at the same time as one's own development.

Following the IPS approach [13], acting for the common good does not necessarily occur as a consequence of merely focusing on skills acquisition. Rather, such socio-personal development occurs when human action proceeds from one's interiority and is oriented towards the overall growth of specific others as much as one's own growth $[13,14]$. Moreover, this model does not conceive of leadership in education as successfully applying 
specific methodologies but rather as knowing how to make sense of education and promote cooperation among colleagues $[11,15]$ and students $[12,16]$.

In order to delimit the study, we have a priori classified the questions addressed to the school principals in the PISA 2018 study into three categories: those about structural aspects of the school, such as its location or its public or private status, which the principals have no power to influence; objective questions about organizational aspects over which the principal has the power to make decisions, such as grouping the students in accordance with their ability, for instance; and finally, subjective questions about issues that the school principal cannot directly act on, such as teachers' perceptions or opinions. We have analyzed the answers which have been given to the entire second group of questions, as well as those to some questions in the first group, with the aim of identifying those variables which correlate with the students' achievement in mathematics, reading and science as well as determining which organizational decisions the principals could make in order to enhance sustainable student development.

The results point to a better long-term achievement on the part of the students when the organizational decisions are based on trust [17] and oriented to enhance interpersonal relationships (teacher-teacher, teacher-student and student-student) in response to the specific needs of each person. This attitude is inseparable from a growth mindset [18], on the part of both school principals and teachers, which believes in the possibility of the growth of all the educational actors, without classifying them in accordance with their performance. Conversely, it seems that the decisions designed merely to control academic life either bear upon academic achievement in a negative way or do not significantly affect it. On the whole, we find out that carefully attending to the interpersonal relationships is the key factor which is behind all the educational policies which generate personal and social development in a sustainable way.

\section{Materials and Methods}

The Program for International Student Assessment (PISA) is a research project, conducted by the Organization for Economic Co-operation and Development (OECD), which evaluates the knowledge and skills gained by 15-year-old students over three-year periods. For the analysis, we have used the answers which were given to the PISA 2018 questionnaires throughout the world [19]. The files available on [19] include the background questionnaires and the data files (from 2000 to 2018) which enable the processing of the data.

The analytical frameworks of the theory underlying PISA surveys, as well as the assessments, can be found in [20]. Since 2000, the design of the questionnaires has been progressively reviewed in order to improve the cross-country comparability of the measured issues [21-23]. This paper focuses on analyzing the correlation between the students' outcomes in mathematics, science and reading (dependent variables) and the answers given by the school principals (independent variables).

The questions addressed to the school principals [8] have been classified into three categories: those about structural aspects of the school; objective questions about organizational aspects over which the principal has the power to make decisions; and subjective questions about issues which the school principal cannot directly act on. For the sake of objectivity, we have only taken the responses given to the entire second group of questions, as well as those to some questions in the first group, as independent variables (a total of 128 variables), distinguishing between the quantitative variables (where the answer is a percentage, a number or an ordinal), shown in Table 1, and the qualitative ones (where the principal is asked to indicate which category the school belongs to), which are shown in Table 2. The first column in each table shows the coding and description of the questions, while the second and third columns show the items (regarded as independent variables) which are dealt with in each question (coding and description). These codes have been taken from the "School questionnaire for PISA 2018. Main survey version" [8]. 
Table 1. Independent quantitative variables.

\begin{tabular}{|c|c|c|}
\hline Question & Variable Code & Variable Description \\
\hline \multirow{3}{*}{$\begin{array}{l}\text { SC016 } \\
\text { About what percentage of your total funding for a typical } \\
\text { school year comes from the following sources? }\end{array}$} & SC016Q01TA & Percentage of the funding sources: government \\
\hline & SC016Q02TA & Percentage of the funding sources: students' families \\
\hline & SC016Q04TA & Percentage of the funding sources: other \\
\hline \multirow{2}{*}{$\begin{array}{l}\text { SC002 } \\
\text { What was the total school enrolment (number of students)? }\end{array}$} & SC002Q01TA & Number of boys \\
\hline & SC002Q02TA & Number of girls \\
\hline \multirow{3}{*}{$\begin{array}{l}\text { SC048 } \\
\begin{array}{l}\text { Please estimate the percentage of students in }<\text { national modal } \\
\text { grade for 15-year-olds }>\text { in your school who have the following } \\
\text { characteristics }\end{array}\end{array}$} & SC048Q01NA & Percentage of students with a native language different from the official one \\
\hline & SC048Q02NA & Percentage of students with special needs \\
\hline & SC048Q03NA & Percentage of students from economically disadvantages homes \\
\hline \multirow{6}{*}{$\begin{array}{l}\text { SC004 } \\
\text { The goal of the following set of questions is to gather } \\
\text { information about the student-computer ratio for students in } \\
\text { the }<\text { national modal grade for } 15 \text {-year-olds }>\text { at your school. }\end{array}$} & SC004Q01TA & Number of 15-years-old students in the school \\
\hline & SC004Q02TA & Number of computers available for15-years-old's students for educational purposes \\
\hline & SC004Q03TA & Number of 15-years-old's computers connected to the internet \\
\hline & SC004Q04NA & Number of 15-years-old's portable computers \\
\hline & SC004Q06NA & Number of data projectors in the school \\
\hline & SC004Q07NA & Number of computers (connected to the internet) available for teachers \\
\hline \multirow{10}{*}{$\begin{array}{l}\text { SC018 } \\
\text { How many of the following teachers are on the staff of your } \\
\text { school? }\end{array}$} & SC018Q01TA01 & Number of full-time teachers on the staff \\
\hline & SC018Q01TA02 & Number of part-time teachers on the staff \\
\hline & SC018Q02TA01 & Number of fully certified fulltime teachers \\
\hline & SC018Q02TA02 & Number of fully certified part-time teachers \\
\hline & SC018Q05NA01 & Number of full-time teachers with a bachelor's degree \\
\hline & SC018Q05NA02 & Number of part-time teachers with a bachelor's degree \\
\hline & SC018Q06NA01 & Number of full-time teachers with a master's degree \\
\hline & SC018Q06NA02 & Number of part-time teachers with a master's degree \\
\hline & SC018Q07NA01 & Number of full-time teachers with a doctor's degree \\
\hline & SC018Q07NA02 & Number of part-time teachers with a doctorate \\
\hline
\end{tabular}


Table 1. Cont.

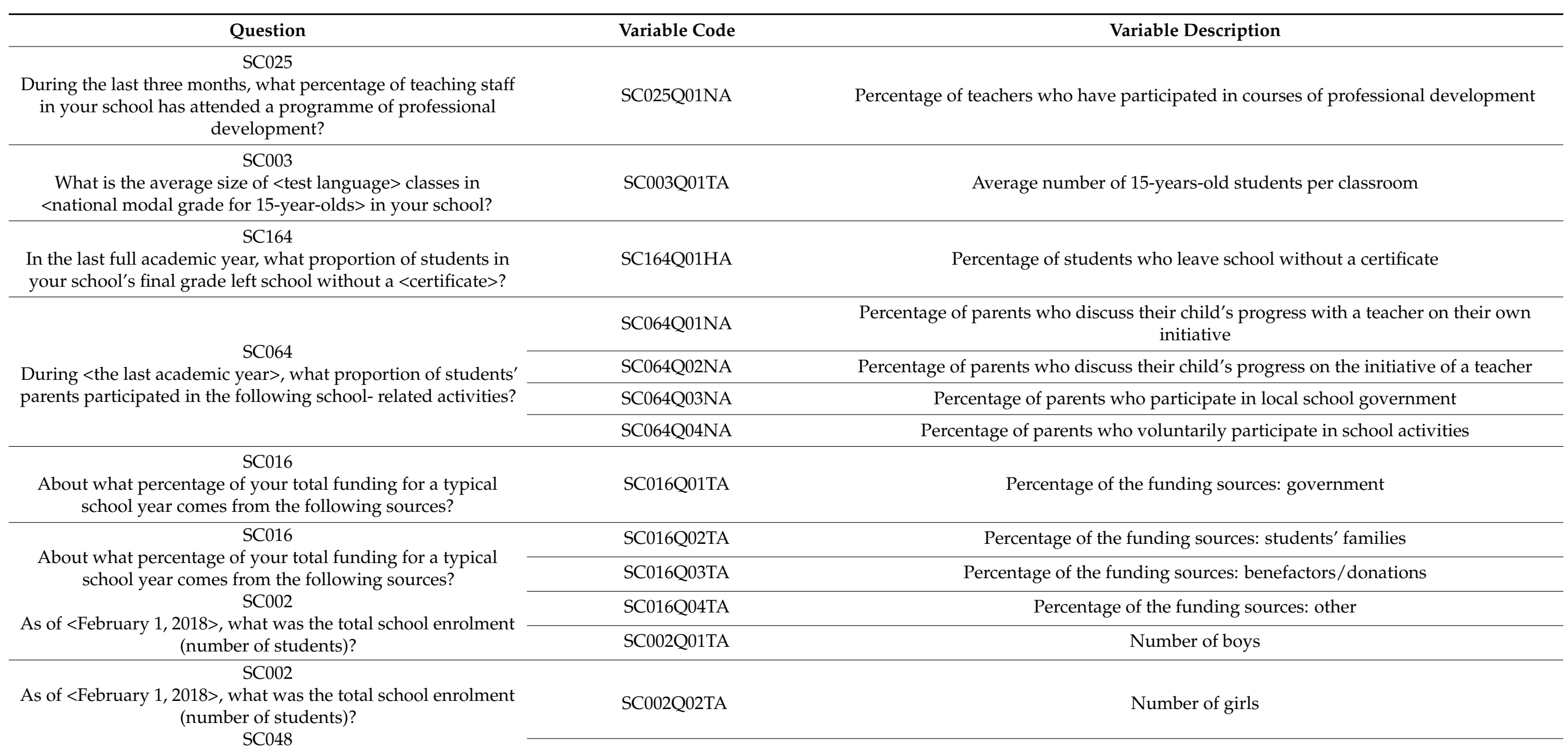

Please estimate the percentage of students in <national modal grade for 15-year-olds $>$ in your school who have the following characteristics.

SC048Q01NA Percentage of students with a native language different from the official one 
Table 1. Cont.

\begin{tabular}{|c|c|c|}
\hline Question & Variable Code & Variable Description \\
\hline \multirow{3}{*}{$\begin{array}{l}\text { SC0 } 48 \\
\begin{array}{c}\text { Please estimate the percentage of students in }<\text { national modal } \\
\text { grade for 15-year-olds }>\text { in your school who have the following } \\
\text { characteristics. } \\
\text { SC004 }\end{array} \\
\text { The goal of the following set of questions is to gather } \\
\text { information about the student-computer ratio for students in } \\
\text { the < national modal grade for 15-year-olds }>\text { at your school }\end{array}$} & & \multirow[b]{2}{*}{ Percentage of students with special needs } \\
\hline & SC048Q02NA & \\
\hline & SC004Q01TA & Number of 15 -years-old students in the school \\
\hline \multirow{6}{*}{$\begin{array}{l}\text { SCO04 } \\
\text { The goal of the following set of questions is to gather } \\
\text { information about the student-computer ratio for students in } \\
\text { the < }<\text { national modal grade for 15-year-olds }>\text { at your school } \\
\text { SC018 } \\
\text { How many of the following teachers are on the staff of your } \\
\text { school? }\end{array}$} & SC004Q03TA & Number of 15-years-old's computers connected to the internet \\
\hline & SC004Q04NA & Number of 15 -years-old's portable computers \\
\hline & SC004Q05NA & Number of interactive whiteboards in the school \\
\hline & SC004Q06NA & Number of data projectors in the school \\
\hline & SC004Q07NA & Number of computers (connected to the internet) available for teachers \\
\hline & SC018Q01TA01 & Number of full-time teachers on the staff \\
\hline \multirow{9}{*}{$\begin{array}{l}\text { SC018 } \\
\text { How many of the following teachers are on the staff of your } \\
\text { school? } \\
\text { SC025 } \\
\text { During the last three months, what percentage of teaching staff } \\
\text { in your school has attended a programme of professional } \\
\text { development? }\end{array}$} & SC018Q02TA01 & Number of fully certified fulltime teachers \\
\hline & SC018Q02TA02 & Number of fully certified part-time teachers \\
\hline & SC018Q05NA01 & Number of fulltime teachers with a bachelor's degree \\
\hline & SC018Q05NA02 & Number of part-time teachers with a bachelor's degree \\
\hline & SC018Q06NA01 & Number of fulltime teachers with a master's degree \\
\hline & SC018Q06NA02 & Number of part-time teachers with a master's degree \\
\hline & SC018Q07NA01 & Number of full-time teachers with a doctor's degree \\
\hline & SC018Q07NA02 & Number of part-time teachers with a doctorate \\
\hline & SC025Q01NA & Percentage of the teachers that have participated in courses of professional development \\
\hline
\end{tabular}

\section{SC003}

What is the average size of $<$ test language $>$ classes in $<$ national modal grade for 15 -year-olds $>$ in your school? 
Table 1. Cont

\begin{tabular}{|c|c|c|}
\hline Question & Variable Code & Variable Description \\
\hline $\begin{array}{l}\text { SC164 } \\
\text { In the last full academic year, what proportion of students in } \\
\text { your school's final grade left school without a }<\text { certificate }>\text { ? }\end{array}$ & SC164Q01HA & Percentage of students who leaves school without a certificate \\
\hline $\begin{array}{l}\text { SC064 } \\
\text { During <the last academic year>, what proportion of students' } \\
\text { parents participated in the following school- related activities? }\end{array}$ & SC064Q01NA & $\begin{array}{c}\text { Percentage of the parents who discusses their child's progress with a teacher on their own } \\
\text { initiative }\end{array}$ \\
\hline \multirow{3}{*}{$\begin{array}{l}\text { SC064 } \\
\text { During <the last academic year }>\text {, what proportion of students' } \\
\text { parents participated in the following school- related activities? }\end{array}$} & SC064Q02NA & Percentage of the parents who discusses their child's progress on a teacher's initiative \\
\hline & SC064Q03NA & Percentage of the parents who participates in local school government \\
\hline & SC064Q04NA & Percentage of the parents who voluntarily participates in the school activities \\
\hline
\end{tabular}

Table 2. Qualitative independent variables.

\begin{tabular}{|c|c|c|}
\hline Question & Variable Code & Variable Description \\
\hline $\begin{array}{l}\text { SC001 } \\
\text { Which of the following definitions best describes the } \\
\text { community in which your school is located? }\end{array}$ & SC001Q01TA & Location of the school: hamlet, village, small town, town, city or large city \\
\hline SC013 & SC013Q01TA & Public or private school \\
\hline \multirow{4}{*}{$\begin{array}{l}\qquad \mathrm{SC161} \\
\text { Is your school a private or a public school? }\end{array}$} & SC161Q01SA & Career guidance for students is not available in the school \\
\hline & SC161Q02SA & All teachers share the responsibility for career guidance \\
\hline & SC161Q04SA & Career guidance: counsellors are employed at the school \\
\hline & SC161Q05SA & Career guidance: counsellors regularly visit the school \\
\hline $\begin{array}{l}\text { SC162 } \\
\text { If career guidance is available at your school, which of the } \\
\text { statements below best describes the situation for students in } \\
<\text { national modal grade for 15-year-olds }>\text { ? }\end{array}$ & SC162Q01SA & $\begin{array}{l}\text { Is there formally scheduled career guidance? (a negation is understood as career guidance } \\
\text { sought voluntarily by students) }\end{array}$ \\
\hline
\end{tabular}


Table 2. Cont.

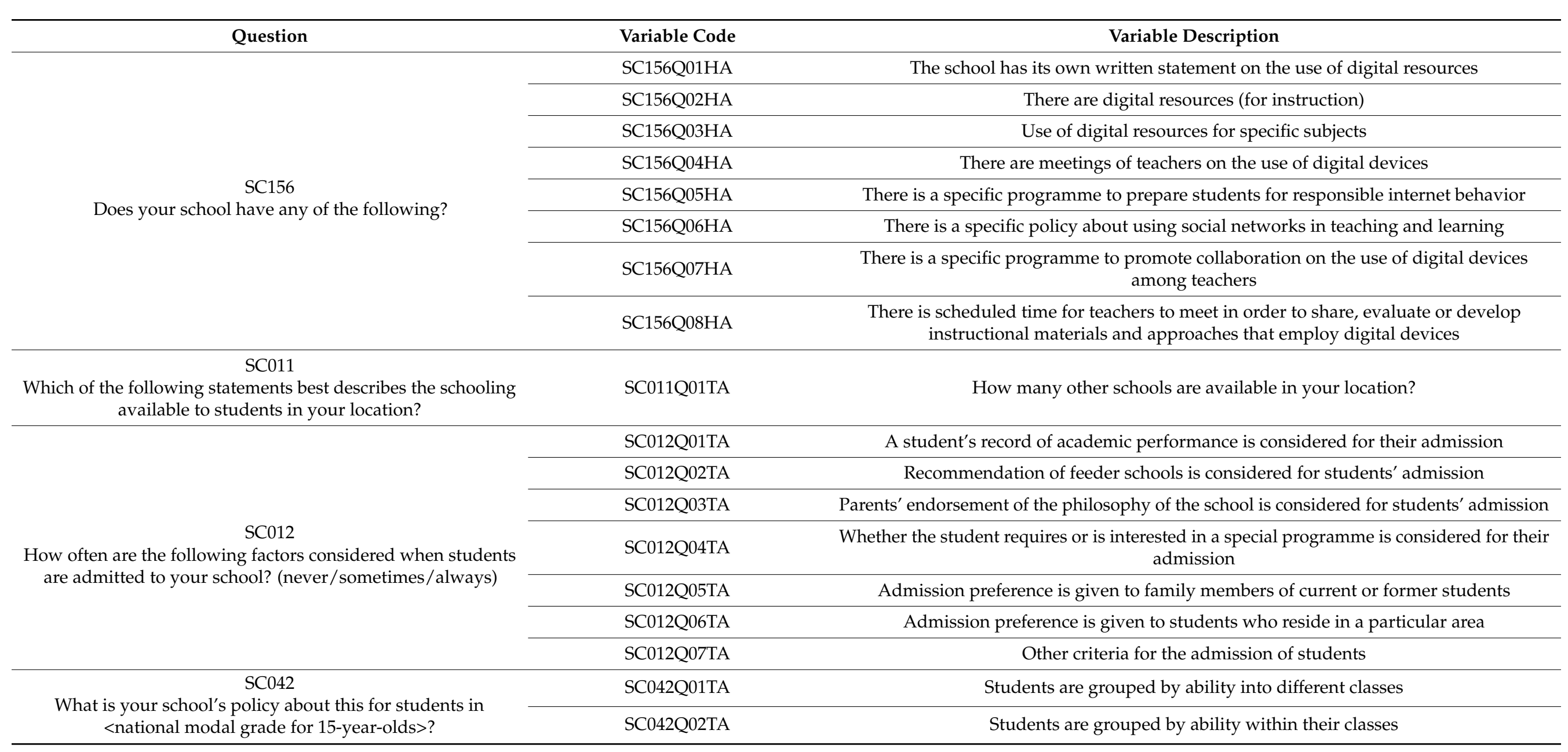


Table 2. Cont.

\begin{tabular}{|c|c|c|}
\hline Question & Variable Code & Variable Description \\
\hline \multirow{11}{*}{$\begin{array}{c}\text { SC154 } \\
\text { In your school, are assessments of students in }<\text { national modal } \\
\text { grade for 15-year-olds }>\text { used for any of the following } \\
\text { purposes? }\end{array}$} & SC154Q01HA & Assessments of students are used to guide students' learning \\
\hline & SC154Q02WA & Assessments of students are used to inform parents about their child's progress \\
\hline & SC154Q03WA & $\begin{array}{c}\text { Assessments of students are used to make decisions about students' retention or } \\
\text { promotion }\end{array}$ \\
\hline & SC154Q04WA & Assessments of students are used to group students for instructional purposes \\
\hline & SC154Q05WA & Assessments of students are used to compare the school to district or national performance \\
\hline & SC154Q06WA & Assessments of students are used to monitor the school's progress from year to year \\
\hline & SC154Q07WA & Assessments of students are used to make judgements about teachers' effectiveness \\
\hline & SC154Q08WA & $\begin{array}{l}\text { Assessments of students are used to identify aspects of instruction or the curriculum that } \\
\text { could be improved }\end{array}$ \\
\hline & SC154Q09HA & Assessments of students are used to adapt teaching to the students' needs \\
\hline & SC154Q10WA & Assessments of students are used to compare the school with other schools \\
\hline & SC154Q11HA & Assessments of students are used to award certificates to students \\
\hline \multirow{3}{*}{$\begin{array}{c}\mathrm{SC} 036 \\
\text { In your school, are achievement data used in any of the } \\
\text { following <accountability procedures }>\text { ? }\end{array}$} & SC036Q01TA & Achievement data are posted publicly (e.g., in the media) \\
\hline & SC036Q02TA & Achievement data are tracked over time by an administrative authority \\
\hline & SC036Q03NA & Achievement data are provided directly to parents \\
\hline \multirow{9}{*}{ 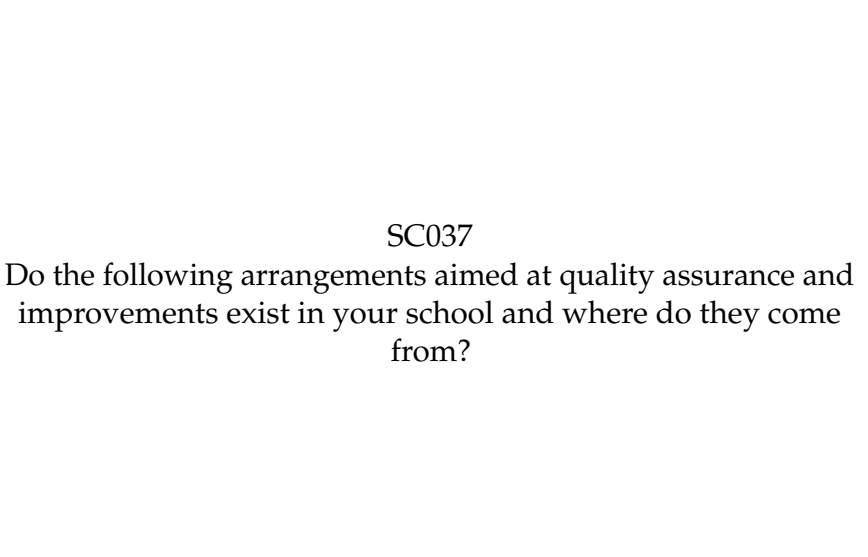 } & SC037Q01TA & Internal evaluation/Self-evaluation of the school \\
\hline & SC037Q02TA & External evaluation of the school \\
\hline & SC037Q03TA & Written specification of the school's curricular profile and educational goals \\
\hline & SC037Q04TA & Written specification of student performance standards \\
\hline & SC037Q05NA & $\begin{array}{c}\begin{array}{c}\text { Systematic recording of data such as teacher or student attendance and professional } \\
\text { development }\end{array} \\
\end{array}$ \\
\hline & SC037Q06NA & Systematic recording of student test results and graduation rates \\
\hline & SC037Q07TA & Seeking written feedback from students (e.g., regarding lessons, teachers or resources) \\
\hline & SC037Q08TA & Teacher mentoring \\
\hline & SC037Q09TA & $\begin{array}{c}\begin{array}{c}\text { Regular consultation with experts over a period of at least six months (aimed at school } \\
\text { improvement) }\end{array}\end{array}$ \\
\hline
\end{tabular}


Table 2. Cont.

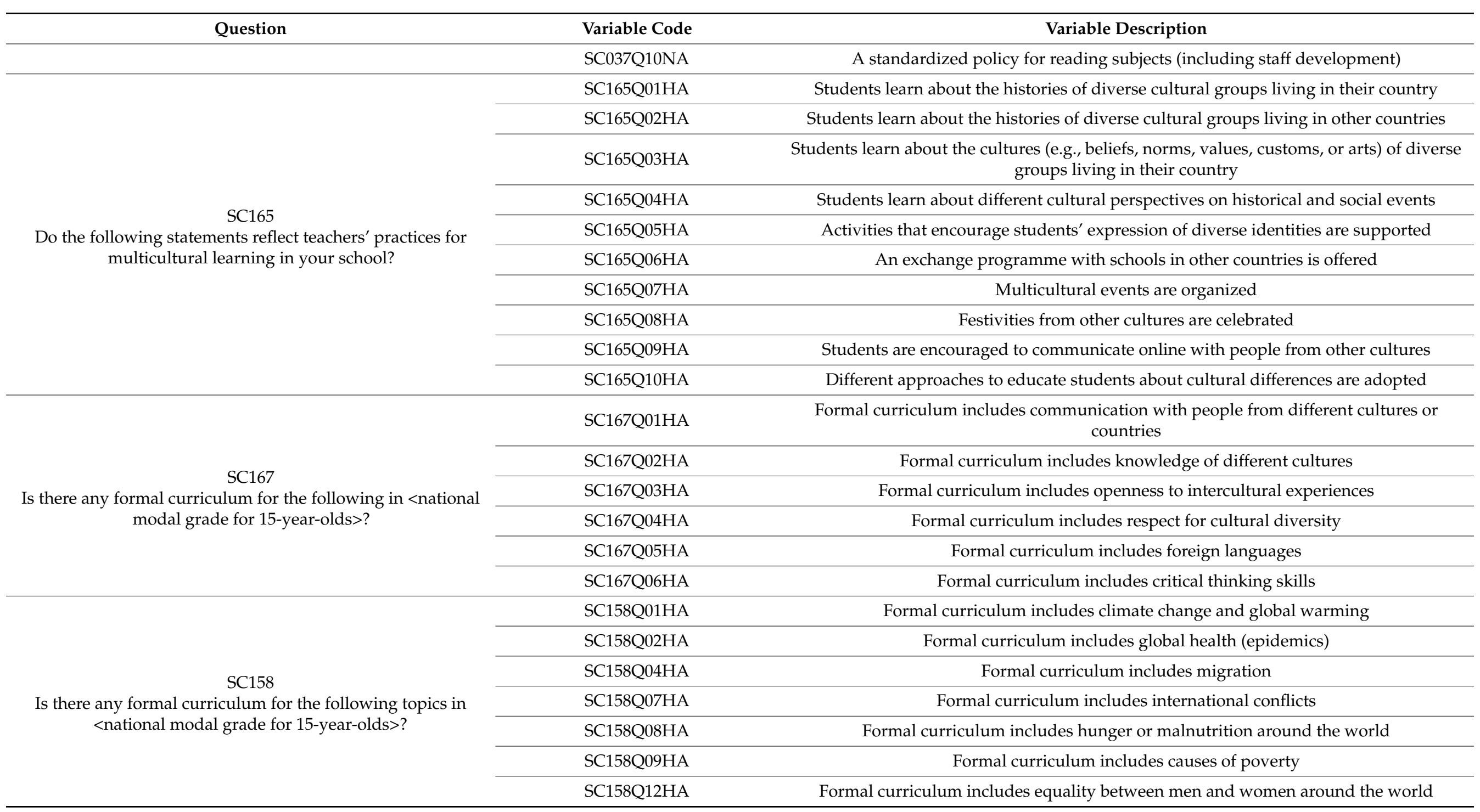


Table 2. Cont.

\begin{tabular}{|c|c|c|}
\hline Question & Variable Code & Variable Description \\
\hline $\begin{array}{c}\text { SC159 } \\
\text { Does your school host visiting teachers from other countries? }\end{array}$ & SC159Q01HA & The school hosts visiting teachers from other countries \\
\hline \multirow{11}{*}{$\begin{array}{c}\text { SC053 } \\
<\text { This academic year }>\text {, which of the following activities does } \\
\text { your school offer to students in the }<\text { national modal grade for } \\
\text { 15-year-olds }>\text { ? }\end{array}$} & SC053Q01TA & The school offers a band, orchestra or choir to students \\
\hline & SC053Q02TA & The school has performed a school play or musical \\
\hline & SC053Q03TA & The school creates a school year-book, newspaper or magazine \\
\hline & SC053Q04TA & The school offers volunteering or service activities to students \\
\hline & SC053Q12IA & The school offers a book club to students \\
\hline & SC053Q13IA & The school offers debating activities to students \\
\hline & SC053Q09TA & The school offers art activities to students \\
\hline & SC053Q10TA & The school offers sporting activities to students \\
\hline & SC053Q14IA & The school offers lectures or seminars by guest speakers \\
\hline & SC053Q15IA & The school offers collaboration with local libraries \\
\hline & SC053Q16IA & The school offers collaboration with local newspapers \\
\hline \multirow{4}{*}{$\begin{array}{l}\text { SC150 } \\
\text { Does your school offer any of the following options to students } \\
\text { in }<\text { national modal grade for } 15 \text {-year-olds }>\text { whose }<\text { heritage } \\
\text { language }>\text { is not the }<\text { test language }>\text { ? }\end{array}$} & SC150Q02HA & $\begin{array}{l}\text { The students with a native language different from the official one attend a preparatory } \\
\text { programme aimed at developing skills in the official language }\end{array}$ \\
\hline & SC150Q03HA & $\begin{array}{c}\begin{array}{c}\text { The students receive some instruction in school subjects through their own language } \\
\text { before transferring to regular classes }\end{array}\end{array}$ \\
\hline & SC150Q04HA & $\begin{array}{l}\text { The students receive a significant amount of instruction in their own language aimed at } \\
\text { developing proficiency in both languages }\end{array}$ \\
\hline & SC150Q05HA & $\begin{array}{l}\text { Class size is reduced to attend to students with a native language different from the official } \\
\text { one }\end{array}$ \\
\hline $\begin{array}{c}\text { SC152 } \\
\text { Does your school offer additional <test language }>\text { lessons } \\
\text { apart from }<\text { test language }>\text { lessons offered during the usual } \\
\text { school hours? }\end{array}$ & SC152Q01HA & Additional lessons in the official language are offered out of regular school hours \\
\hline
\end{tabular}


Table 2. Cont

\begin{tabular}{|c|c|c|}
\hline Question & Variable Code & Variable Description \\
\hline $\begin{array}{c}\text { SC160 } \\
\text { What is the purpose of these additional <test language }> \\
\text { lessons? }\end{array}$ & SC160Q01WA & $\begin{array}{l}\text { Which is the purpose of the additional lessons on the official language (enrichment or } \\
\text { remedial) }\end{array}$ \\
\hline \multirow{2}{*}{$\begin{array}{l}\text { SC052 } \\
\text { For 15-year-old students, does your school provide the } \\
\text { following study help? }\end{array}$} & SC052Q02NA & Staff help with homework \\
\hline & SC052Q03HA & Peer-to-peer tutoring \\
\hline
\end{tabular}


The goal is to identify which of these variables bear on the students' outcomes in mathematics, science and reading (dependent variables) in order to know how sustainable improvement might be achieved by the principal of a school.

As dependent variables we have taken the mean values of the scores obtained by the school in the general skills evaluated in each competence (mathematics, science and reading [19]), which have been obtained as a result of computing the average of the marks achieved by the students in each of the ten values collected in the test for each discipline. After eliminating the schools with less than nine respondents, we have considered a total of 17,995 schools (some of them with questionnaires only partially completed) located in 79 countries (with an average of around 228 schools per country). Luxemburg is the country with the minimum number of participating schools (40), while Spain has the maximum number (1011). We have estimated that a total of 564,282 students have been considered in the study.

In order to identify the variables that might bear upon the marks obtained in the tests (in mathematics, reading and science) we carried out two kinds of analyses.

For each quantitative variable in Table 1, a Pearson correlation coefficient was computed (in Table 3) to measure the strength of a linear association between this quantitative variable and the mean values of the scores in each competence (mathematics, science and reading). Correlations between 0.1 and 0.3 will be regarded as "weak correlations" and correlations higher than 0.3 , as "intermediate" correlations. These benchmarks are also taken as significant in other papers [24,25].

Each qualitative variable (in Table 2) classifies the schools into several categories (public or private, for instance). For each qualitative variable, a one-way ANOVA test was carried out to analyze if there are any statistically significant differences between the means of the scores in each competence corresponding to different categories (the null hypothesis being that there are no differences between these mean values). The large size of the sample enabled most of the analyses to accept that these differences are statistically significant even when there is a relatively low significance level. We decided to regard the influence of a variable as statistically significant whenever the differences between the averages corresponding to different categories of the variable were over $4 \%$ of the average score (around 420 points), i.e., over 20 points. These values correspond to an effect of the Cohen size of $d=0.2$. These benchmarks have been recently established by Kraft [26], who argues that, in an educational context, it may be more justified than in others to interpret respectively $\mathrm{d}<0.05, \mathrm{~d}<0.20$ and $\mathrm{d}>0.50$ as "small", "medium" and "large" effect sizes.

In this paper, the analysis was carried out with Statgraphics Centurion XVII software (2014, Statpoint Technologies, Inc., The Plains, VA, USA).

\section{Results}

The correlation between the marks obtained in each pair of disciplines is very high: 0.9407 between Mathematics and Reading; 0.9642 between Mathematics and Science; and 0.9725 between Reading and Science.

Table 3 shows the Pearson correlation coefficients between the variables in Table 1 and the averages of the values obtained in Mathematics, Reading and Science. 
Table 3. Pearson correlation coefficients between the numerical variables and the dependent ones.

\begin{tabular}{|c|c|c|c|c|}
\hline Variable Code & Variable Description & Maths Mean & Science Mean & Reading Mean \\
\hline SC016Q01TA & Percentage of the funding sources: government & -0.0367 & -0.0539 & -0.0526 \\
\hline SC016Q02TA & Percentage of the funding sources: students' families & 0.0778 & 0.0927 & 0.0935 \\
\hline SC016Q03TA & Percentage of the funding sources: benefactors/donations & -0.0790 & -0.0655 & -0.0727 \\
\hline SC016Q04TA & Percentage of the funding sources: other & -0.0366 & -0.0362 & -0.0363 \\
\hline SC002Q01TA & Number of boys & 0.1214 & 0.1208 & 0.0898 \\
\hline SC002Q02TA & Number of girls & 0.1351 & 0.1520 & 0.1604 \\
\hline SC048Q01NA & $\begin{array}{l}\text { Percentage of students with a native language different from } \\
\text { the official one }\end{array}$ & -0.0762 & -0.1076 & -0.1290 \\
\hline SC048Q03NA & $\begin{array}{l}\text { Percentage of students from socioeconomically } \\
\text { disadvantaged homes }\end{array}$ & -0.4449 & -0.4171 & -0.4017 \\
\hline SC004Q01TA & Number of 15-years-old students in the school & 0.0978 & 0.1160 & 0.0992 \\
\hline SC004Q02TA & $\begin{array}{l}\text { Number of computers available for 15-years-old students for } \\
\text { educational purposes }\end{array}$ & 0.2599 & 0.2669 & 0.2480 \\
\hline SC004Q03TA & $\begin{array}{l}\text { Number of computers connected to the internet available for } \\
15 \text {-years-old students }\end{array}$ & 0.2821 & 0.2909 & 0.2726 \\
\hline SC004Q04NA & $\begin{array}{l}\text { Number of portable computers available for 15-years-old } \\
\text { students }\end{array}$ & 0.1993 & 0.274 & 0.2203 \\
\hline SC004Q06NA & Number of data projectors in the school & 0.4079 & 0.4034 & 0.3868 \\
\hline SC004Q07NA & $\begin{array}{l}\text { Number of computers (connected to the internet) available } \\
\text { for teachers }\end{array}$ & 0.3443 & 0.3427 & 0.3169 \\
\hline SC018Q01TA01 & Number of full-time teachers on the staff & 0.2274 & 0.2169 & 0.1909 \\
\hline SC018Q01TA02 & Number of part-time teachers on the staff & -0.0102 & 0.0052 & 0.0168 \\
\hline SC018Q02TA01 & Number of fully certified full-time teachers & 0.3128 & 0.3002 & 0.2647 \\
\hline SC018Q02TA02 & Number of fully certified part-time teachers & 0.0131 & 0.0335 & 0.0498 \\
\hline SC018Q05NA01 & Number of full-time teachers with a bachelor's degree & 0.1662 & 0.1798 & 0.1492 \\
\hline SC018Q05NA02 & Number of part-time teachers with a bachelor's degree & -0.0565 & -0.0246 & -0.0077 \\
\hline SC018Q06NA01 & Number of full-time teachers with a master's degree & 0.2882 & 0.2581 & 0.2495 \\
\hline SC018Q06NA02 & Number of part-time teachers with a master's degree & 0.1387 & 0.1352 & 0.1432 \\
\hline SC018Q07NA01 & Number of full-time teachers with a doctorate & 0.1208 & 0.1110 & 0.1118 \\
\hline SC018Q07NA02 & Number of part-time teachers with a doctorate & 0.0423 & 0.0441 & 0.0493 \\
\hline SC025Q01NA & $\begin{array}{l}\text { Percentage of teachers who have participated in courses of } \\
\text { professional development }\end{array}$ & 0.1235 & 0.1363 & 0.1267 \\
\hline
\end{tabular}


Table 3. Cont.

\begin{tabular}{|c|c|c|c|c|}
\hline Variable Code & Variable Description & Maths Mean & Science Mean & Reading Mean \\
\hline SC003Q01TA & Average number of 15-years-old students per classroom & -0.1119 & -0.0664 & -0.0673 \\
\hline SC164Q01HA & Percentage of students who leave school without a certificate & -0.1699 & -0.1428 & -0.1392 \\
\hline SC064Q01NA & $\begin{array}{l}\text { Percentage of parents who discuss their child's progress } \\
\text { with a teacher on their own initiative }\end{array}$ & 0.1214 & 0.0971 & 0.0906 \\
\hline SC064Q02NA & $\begin{array}{c}\text { Percentage of parents who discuss their child's progress on } \\
\text { the initiative of a teacher }\end{array}$ & 0.1264 & 0.1065 & 0.0989 \\
\hline SC064Q03NA & $\begin{array}{c}\text { Percentage of parents who participate in local school } \\
\text { government }\end{array}$ & -0.2151 & -0.23 & -0.2381 \\
\hline SC064Q04NA & $\begin{array}{l}\text { Percentage of parents who voluntarily participate in school } \\
\text { activities }\end{array}$ & -0.0829 & -0.1043 & -0.1192 \\
\hline
\end{tabular}


The positive correlations have been highlighted in orange. This means that the higher the variable value is, the higher the average of the marks is in the corresponding discipline. A light orange means that the correlation is weak (between 0.1 and 0.3). A dark orange shows an intermediate correlation (over 0.3). The negative correlations are shown in blue. This means that the higher the variable is, the lower the average of the marks is in the corresponding discipline. The weak correlations (with values between -0.1 and -0.3 ) are highlighted in light blue. A dark blue is used to show correlations lower than -0.3 , which have an intermediate intensity. Results which are not statistically significant are shown in green.

The variables with a weak positive correlation with all three disciplines are: number of girls, number of computers available for teaching, how many of them are connected to the internet, how many of them are portable; number of interactive whiteboards, number of full-time teachers on the school staff, number of full-time teachers with a bachelor's degree, number of full-time teachers with a master's degree, number of part-time teachers with a master's degree, number of full-time teachers with a doctorate and percentage of teachers who have participated in professional development courses in the previous three months.

The variables with a positive intermediate correlation are: number of projectors in the school and number of computers connected to the internet for teachers. The number of full-time teachers with a degree shows positive correlations of intermediate intensity with both mathematics and science, while showing a positive weak correlation with reading.

The variables with a negative weak correlation with the three disciplines are: percentage of student dropouts and percentage of parents who participate in local school government. Other variables with a negative weak correlation with only two disciplines are: percentage of students with a native language different from the official one and percentage of parents who voluntarily participate in the activities of the school.

The variable with a negative intermediate correlation with all three disciplines is the percentage of students from socioeconomically disadvantaged homes.

Table 4 shows the F-ratio of the ANOVA analysis which has been carried out for each qualitative variable. Each qualitative variable divides the schools into several categories. The higher the F-ratio is, the higher the differences are between the means in a discipline corresponding to the different categories. For instance, the differences between the means corresponding to private or public schools are statistically significant.

In Table 4 the qualitative variables which bear upon the average marks (in a certain discipline) have been colored in blue. The rest are colored in green. A dark blue has been used to highlight the differences between the average marks corresponding to the different categories of the independent variable when they are higher than 20 points (at least between two of the levels). Table 5 explains which category gives the best scores in each case (colored in blue). 
Table 4. F-ratio del test ANOVA between each qualitative variable and the dependent ones.

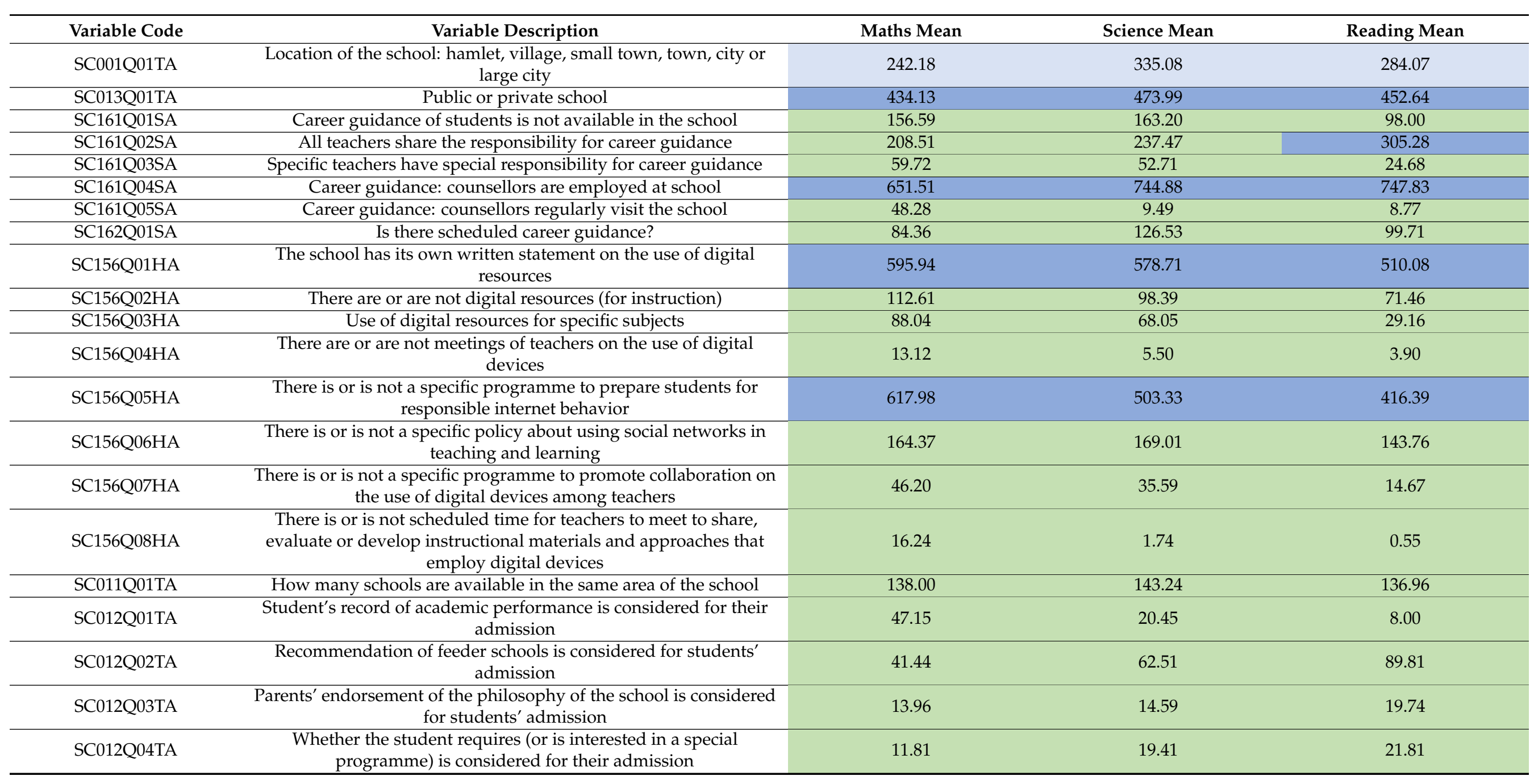


Table 4. Cont

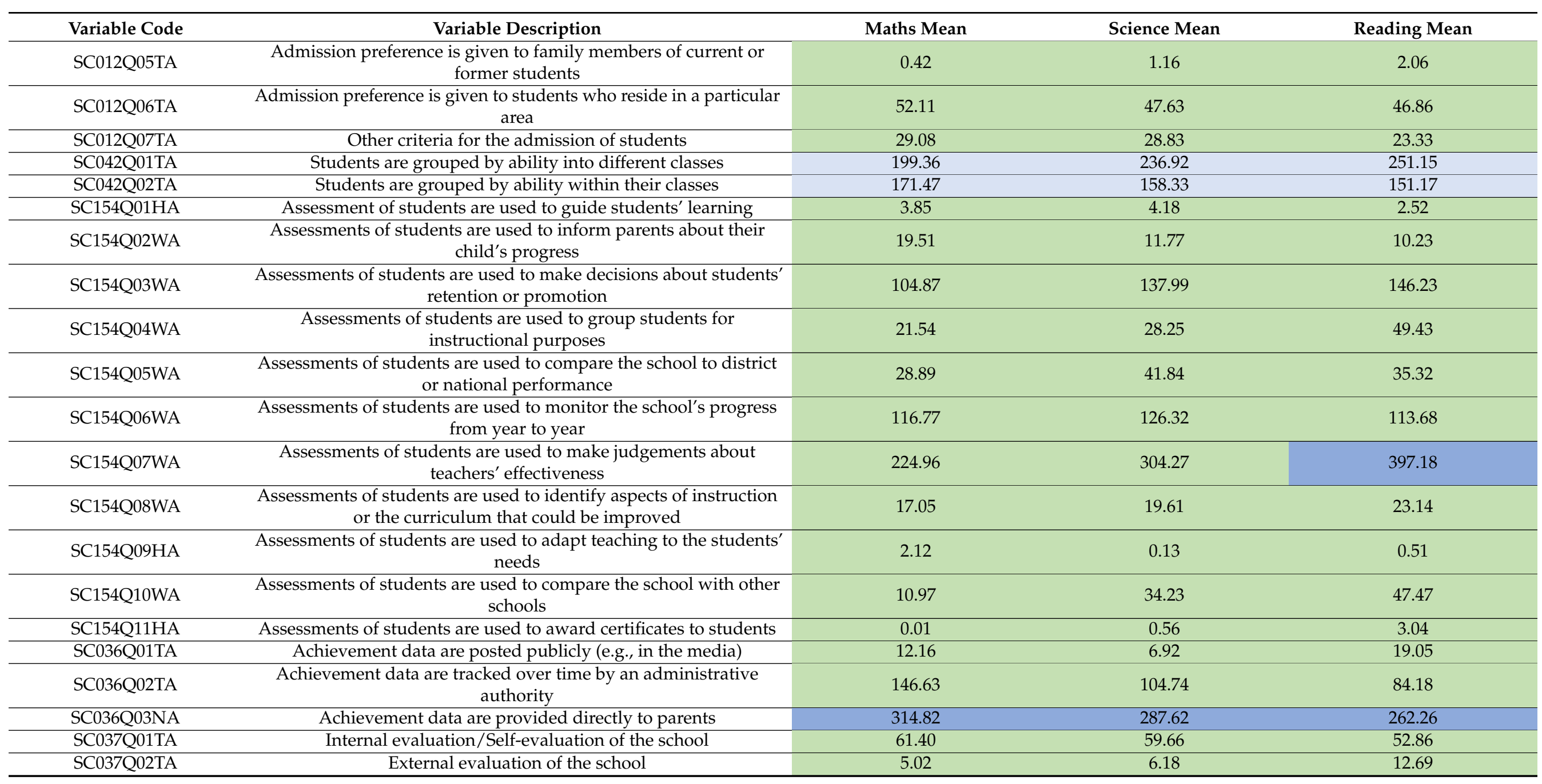


Table 4. Cont

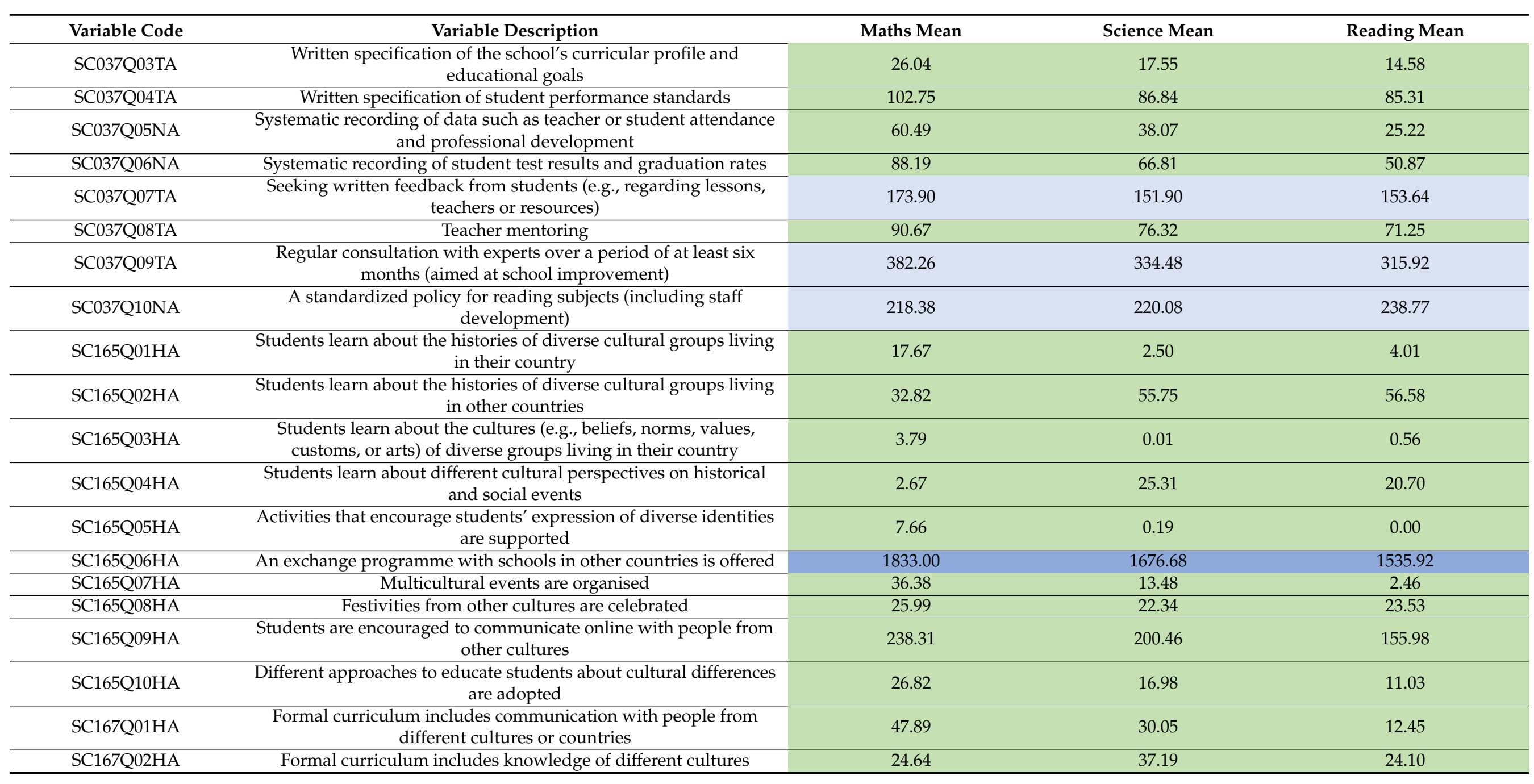


Table 4. Cont.

\begin{tabular}{|c|c|c|c|c|}
\hline Variable Code & Variable Description & Maths Mean & Science Mean & Reading Mean \\
\hline SC167Q03HA & Formal curriculum includes openness to intercultural experiences & 64.54 & 55.52 & 30.89 \\
\hline SC167Q04HA & Formal curriculum includes respect for cultural diversity & 1.10 & 5.94 & 2.52 \\
\hline SC167Q05HA & Formal curriculum includes foreign languages & 139.39 & 135.05 & 167.00 \\
\hline SC167Q06HA & Formal curriculum includes critical thinking skills & 16.20 & 23.33 & 16.12 \\
\hline SC158Q01HA & Formal curriculum includes climate change and global warming & 111.45 & 174.46 & 132.89 \\
\hline SC158Q02HA & Formal curriculum includes global health (epidemics) & 18.04 & 42.52 & 30.08 \\
\hline SC158Q04HA & Formal curriculum includes migration & 85.77 & 136.79 & 113.26 \\
\hline SC158Q07HA & Formal curriculum includes international conflicts & 175.91 & 273.58 & 249.52 \\
\hline SC158Q09HA & Formal curriculum includes causes of poverty & 37.22 & 80.80 & 64.56 \\
\hline SC158Q12HA & $\begin{array}{l}\text { Formal curriculum includes equality between men and women } \\
\text { around the world }\end{array}$ & 7.53 & 25.55 & 18.43 \\
\hline SC159Q01HA & The school hosts visiting teachers from other countries & 1270.08 & 1042.34 & 917.99 \\
\hline SC053Q01TA & The school offers a band, orchestra or choir to students & 1048.20 & 1200.48 & 1171.58 \\
\hline SC053Q02TA & The school has performed a school play or musical & 316.82 & 370.28 & 400.17 \\
\hline SC053Q03TA & The school creates a school year-book, newspaper or magazine & 594.98 & 508.11 & 391.46 \\
\hline SC053Q04TA & The school offers volunteering or service activities to students & 166.25 & 155.72 & 106.01 \\
\hline SC053Q13IA & The school offers debating activities to students & 75.98 & 98.99 & 108.87 \\
\hline SC053Q09TA & The school offers art activities to students & 49.38 & 73.47 & 51.29 \\
\hline SC053Q10TA & The school offers sporting activities to students & 5.28 & 7.29 & 2.0 \\
\hline SC053Q14IA & The school offers lectures or seminars by guest speakers & 788.34 & 745.64 & 739.34 \\
\hline SC053Q15IA & The school offers collaboration with local libraries & 42.77 & 3.12 & 2.21 \\
\hline SC053Q16IA & The school offers collaboration with local newspapers & 73.42 & 24.37 & 15.78 \\
\hline SC150Q01IA & $\begin{array}{c}\text { The students with a native language different from the official one } \\
\text { receive instruction aimed at developing skills in the official } \\
\text { language }\end{array}$ & 330.34 & 237.28 & 227.88 \\
\hline SC150Q02IA & $\begin{array}{l}\text { The students with a native language different from the official one } \\
\text { attend a preparatory programme aimed at developing skills in the } \\
\text { official language }\end{array}$ & 71.09 & 47.21 & 28.26 \\
\hline
\end{tabular}


Table 4. Cont

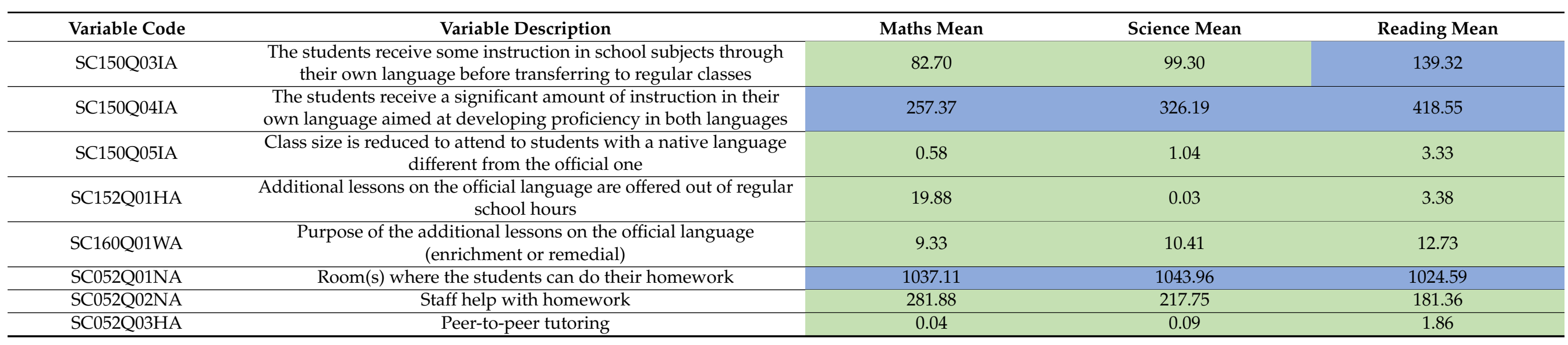

Table 5. Averages of the dependent variables corresponding to significant differences between levels of the qualitative factor.

\begin{tabular}{|c|c|c|c|c|c|}
\hline & Variable & Category & Maths Mean & Science Mean & Reading Mean \\
\hline \multirow{5}{*}{ SC001Q01TA } & \multirow{5}{*}{$\begin{array}{l}\text { Which of the following definitions best describes } \\
\text { the community in which your school is located? }\end{array}$} & $\begin{array}{l}\text { A village, hamlet or rural area (fewer } \\
\text { than } 3000 \text { people) }\end{array}$ & 419.933 & 419.363 & 409.476 \\
\hline & & A small town (3000 to about 15,000$)$ & 448.396 & 448.595 & 441.701 \\
\hline & & A town $(15,000$ to about 100,000$)$ & 459.337 & 459.341 & 455.315 \\
\hline & & A city $(100,000$ to about $1,000,000)$ & 468.135 & 468.718 & 465.787 \\
\hline & & A large city (with over $1,000,000$ ) & 482.758 & 484.925 & 483.161 \\
\hline \multirow{2}{*}{ SC013Q01TA } & \multirow{2}{*}{ Is your school a public or a private school? } & A public school & 451.053 & 451.865 & 446.784 \\
\hline & & A private school & 480.997 & 482.046 & 477.687 \\
\hline \multirow{2}{*}{ SC161Q02SA } & All teachers share the responsibility for career & Non & 467.331 & 467.543 & 464.452 \\
\hline & guidance & Yes & 450.584 & 450.312 & 443.953 \\
\hline \multirow{2}{*}{ SC161Q04SA } & We have one or more specific career guidance & Non & 449.751 & 449.453 & 444.53 \\
\hline & counsellors employed at school & Yes & 478.634 & 479.175 & 475.835 \\
\hline \multirow{2}{*}{ SC156Q01HA } & Its own written statement about the use of & Yes & 470.787 & 470.787 & 466.152 \\
\hline & digital devices & Non & 443.323 & 443.323 & 440.343 \\
\hline \multirow{2}{*}{ SC156Q05HA } & A specific programme to prepare students for & Yes & 471.55 & 470.38 & 465.688 \\
\hline & responsible internet behaviour & Non & 443.882 & 446.239 & 442.544 \\
\hline
\end{tabular}


Table 5. Cont.

\begin{tabular}{|c|c|c|c|c|c|}
\hline & Variable & Category & Maths Mean & Science Mean & Reading Mean \\
\hline \multirow{3}{*}{ SC042Q01TA } & \multirow{3}{*}{$\begin{array}{l}\text { Students are grouped by ability into different } \\
\text { classes. }\end{array}$} & For all subjects & 437.699 & 437.652 & 429.544 \\
\hline & & For some subjects & 474.021 & 475.313 & 471.206 \\
\hline & & Not for any subjects & 458.478 & 458.153 & 454.543 \\
\hline \multirow{2}{*}{ SC042Q02TA } & \multirow{2}{*}{$\begin{array}{c}\text { Students are grouped by ability within their } \\
\text { classes. }\end{array}$} & For some subjects & 469.337 & 468.428 & 463.585 \\
\hline & & Not for any subjects & 459.406 & 460.304 & 457.024 \\
\hline \multirow{2}{*}{ SC154Q07WA } & \multirow{2}{*}{$\begin{array}{l}\text { Are assessments of students used to make } \\
\text { judgements about teachers' effectiveness }\end{array}$} & Yes & 453.976 & 453.412 & 447.689 \\
\hline & & Non & 470.863 & 472.315 & 470.306 \\
\hline SC036Q03NA & $\begin{array}{l}\text { Achievement data are provided directly to } \\
\text { parents }\end{array}$ & Non & 483.915 & 482.352 & 478.171 \\
\hline \multirow{3}{*}{ SC037Q07TA } & \multirow{3}{*}{$\begin{array}{c}\text { Seeking written feedback from students for } \\
\text { aimed quality assurance (e.g., regarding lessons, } \\
\text { teachers or resources) }\end{array}$} & Yes, this is mandatory & 441.631 & 444.121 & 439.14 \\
\hline & & Yes, based on school initiative & 464.119 & 464.016 & 459.124 \\
\hline & & No & 460.055 & 460.211 & 457.791 \\
\hline \multirow{3}{*}{ SC037Q09TA } & \multirow{3}{*}{$\begin{array}{c}\text { Regular consultation aimed at school } \\
\text { improvement with one or more experts over a } \\
\text { period of at least six months } \\
\end{array}$} & Yes, this is mandatory & 437.85 & 440.634 & 435.591 \\
\hline & & Yes, based on school initiative & 461.404 & 461.036 & 456.243 \\
\hline & & No & 467.386 & 467.374 & 463.91 \\
\hline \multirow{2}{*}{ SC037Q10NA } & \multirow{2}{*}{$\begin{array}{l}\text { Implementation of a standardised policy for } \\
\text { reading subjects }\end{array}$} & Yes, this is mandatory & 444.368 & 445.222 & 439.58 \\
\hline & & Yes, based on school initiative & 465.189 & 465.192 & 461.278 \\
\hline \multirow{2}{*}{ SC165Q06HA } & \multirow{2}{*}{$\begin{array}{l}\text { Our school offers an exchange programme with } \\
\text { schools in other countries. }\end{array}$} & Yes & 481.83 & 480.422 & 477.425 \\
\hline & & Non & 433.111 & 435.766 & 431.389 \\
\hline \multirow{2}{*}{ SC167Q05HA } & Is there any formal curriculum for the foreign & Yes & 457.282 & 457.488 & 454.345 \\
\hline & languages & Non & 434.021 & 435.57 & 428.266 \\
\hline \multirow{2}{*}{ SC158Q07HA } & Is there any formal curriculum for the & Yes & 459.602 & 460.715 & 457.05 \\
\hline & international conflicts & Non & 440.738 & 438.348 & 434.203 \\
\hline \multirow{2}{*}{ SC159Q01HA } & Does your school host visiting teachers from & Yes & 485.041 & 482.387 & 477.695 \\
\hline & other countries? & Non & 444.746 & 446.989 & 442.675 \\
\hline \multirow{2}{*}{ SC053Q01TA } & Activities which your school offer to students: & Yes & 476.33 & 476.981 & 473.375 \\
\hline & Band, orchestra, or choir & Non & 440.831 & 440.478 & 435.516 \\
\hline \multirow{2}{*}{ SC053Q02TA } & Activities which your school offer to students: & Yes & 468.996 & 469.566 & 466.086 \\
\hline & School play or school musical & Non & 448.851 & 448.591 & 443.217 \\
\hline
\end{tabular}


Table 5. Cont.

\begin{tabular}{|c|c|c|c|c|c|}
\hline & Variable & Category & Maths Mean & Science Mean & Reading Mean \\
\hline \multirow{2}{*}{ SC053Q03TA } & Activities which your school offer to students: & Yes & 473.767 & 472.64 & 467.563 \\
\hline & School yearbook, newspaper or magazine & Non & 446.911 & 448.634 & 445.384 \\
\hline \multirow{2}{*}{ SC053Q14IA } & Activities which your school offer to students: & Yes & 470.196 & 469.875 & 466.06 \\
\hline & Lectures and/or seminars & Non & 435.327 & 437.135 & 431.847 \\
\hline \multirow{2}{*}{ SC150Q01IA } & $\begin{array}{l}\text { The students whose native language is not the } \\
\text { official one attend regular classes and receive }\end{array}$ & Yes & 471.352 & 469.425 & 465.773 \\
\hline & $\begin{array}{l}\text { additional periods of instruction aimed at } \\
\text { developing official language skills }\end{array}$ & Non & 450.813 & 452.582 & 448.414 \\
\hline \multirow{2}{*}{ SC150Q03IA } & $\begin{array}{l}\text { Before transferring to regular classes, the } \\
\text { students whose native language is not the }\end{array}$ & Yes & 447.842 & 446.934 & 439.56 \\
\hline & $\begin{array}{l}\text { official one receive some instruction in school } \\
\text { subjects through their native language }\end{array}$ & Non & 463.286 & 463.256 & 459.856 \\
\hline \multirow{2}{*}{ SC150Q04IA } & $\begin{array}{l}\text { The students whose native language is not the } \\
\text { official one receive significant amounts of }\end{array}$ & Yes & 439.498 & 437.534 & 429.205 \\
\hline & $\begin{array}{l}\text { instruction in their native language aimed at } \\
\text { developing proficiency in both languages }\end{array}$ & Non & 465.044 & 465.234 & 462.094 \\
\hline \multirow{2}{*}{ SC052Q01NA } & The school provide room(s) where the students & Yes & 473.362 & 473.22 & 469.453 \\
\hline & can do their homework & Non & 436.593 & 437.664 & 432.421 \\
\hline
\end{tabular}


The qualitative variables that bear upon all three disciplines, with differences higher than 20 points between categories, are: whether the school is public or private (with higher marks in the private case), whether the achievement data of the students are provided directly to parents (with better scores in the negative case), whether there are counsellors employed by the school for the career guidance of students, whether there are digital devices for a general use, whether there is a specific programme to educate students in responsible internet behavior, whether an exchange programme with schools in other countries is offered, whether the school hosts visiting teachers from other countries, whether group musical activities are offered, whether a school play or musical has been organized, whether there is a school newspaper or magazine, whether lectures or seminars are offered and whether the school has rooms where the students can do their homework. In all these cases, the positive answers to the question give higher marks in the three disciplines.

There are other qualitative variables which give lower differences between categories for the three analyzed subjects, such as the location of the school (the larger the town is, the higher the marks are), whether the school offers an exchange programme with schools in other countries, resulting in an improvement in marks, or whether the students are grouped by ability either into different classes or within their classes, with the lowest marks in the case of their being grouped for all the subjects. However, if they are grouped for only some subjects, the marks are even higher than in the case of no grouping at all. Another factor which gives differences between levels lower than 20 points are whether written feedback (regarding lessons, teachers or resources) is sought from the students compulsorily, and with less differences (vis-à-vis the case of no feedback) when the school carries out this feedback on their own initiative. Finally, whether there is a regular consultation with experts aimed at school improvement bears upon the marks of the three disciplines in a negative way, the same as whether the students whose native language is not the official one receive instruction in their native language aimed at developing proficiency in both languages or if there is not a standardized policy for reading subjects (including staff development). However, if this policy is an initiative on the part of the school, there appear intermediate differences in the marks corresponding to the three disciplines vis-à-vis the case of no policy for reading subjects.

Other variables bear upon the reading subject only (with differences of over 20 points between levels of the factor) in a negative way (i.e., leading to lower marks), such as all teachers sharing the responsibility for the career guidance of the students, or the students' assessments being used to make judgements about teachers' effectiveness. In the case of the students with a native language different from the official one, the only practice that has a positive influence on the marks (and this only in mathematics) is offering the students additional periods of instruction aimed at developing skills in the official language, at the same time as their attending regular classes.

Finally, whether the formal curriculum includes the topic of international conflicts is significant in improving the results in both science and reading.

\section{Discussion}

The analysis of the results aims to identify a common denominator for the factors which correlate with good academic scores in the three disciplines which have been considered in the study. Our thesis is that this common denominator is a careful attention to interpersonal relationships (teacher-teacher, teacher-student, student-student and also student-families) as opposed to a merely cognitive educational perspective or a desire to control the educational process. This means that relationships based on trust seem to result in improved academic scores. This interpretation is aligned with the study known as the McKinsey report, which analyses twenty educational systems around the world by means of the data provided by several international assessment tests (PISA, PIRLS, TIMSS, etc.). According to this report, systems with the same economic investment in education obtain diverse results. The conclusion of the report is that the differences in terms of quality are 
not attributable to the investment, but rather to the teachers: "The quality of an educational system cannot exceed the quality of its teachers" [27].

In order to enhance the quality of teachers, it is clear that attending to interpersonal relationships is one of the main objectives to consider. However, enhancing interpersonal relationships is not the same as working on socio-emotional skills. In fact, the complexity of the educational reality cannot be addressed by means of the inclusion of a programme of emotional skills in the school curricula, as some authors have suggested, arguing that the school is excessively focused on cognitive skills. As will be seen, the research into non-cognitive skills has produced diverse results.

On the one hand, a meta-analysis which reviews the papers published between 2013 and 2017 on this topic [28] asserts that the correlation between students' achievement in non-cognitive skills and their academic performance is relatively low and also diverse; working on non-cognitive skills has had a positive effect on some students, a negative effect on others, and no effect on the remainder.

On the other hand, another meta-analysis in 2017 [29] showed that socio-emotional learning is effective in the acquisition of certain socio-emotional skills and some particular attitudes. For instance, this analysis concluded that there is a correlation between working on these skills and attitudes during youth, and such factors as academic success or safe sexual behavior.

A third meta-analysis which has been considered [30] concludes that emotional intelligence is the third predictor of academic performance, after cognitive intelligence and conscientiousness, but only with a percentage of between 0.7 and 3.6 of the variance, which is regarded as a low significance.

Although there are unresolved questions regarding how to interpret and evaluate the influence of emotional factors on academic performance, what does seem to be clear is the impact of interpersonal relationships on academic results. Comprehensive reviews of this topic can be seen in $[31,32]$. This suggests that it is the interpersonal relationships, and not the emotional skills, which are decisive when it comes to offering an educational experience that enhances sustainable personal and social growth.

An analysis of the results obtained in our study supports this argument. Firstly, we find some specific non-personal factors which correlate with good academic outcomes, such as the number of data projectors or the number of computers for the teachers' use. Rather than presuppose that the impact on student achievement is due to their presence per se, we recognize that the impact in question might be attributable to a more fruitful interaction between the teacher and the students when a computer or a projector is being used in the classroom.

Similarly, although the socioeconomic situation of the families significantly bears upon the academic outcomes, it is surprising that other economic variables, such as the funding sources (parents, government or benefactors) or the area of the town in which the families reside, are not relevant in this regard. This suggests that the significant aspect is the family experience of the students, rather than the economic factor.

In addition, there are some striking organizational aspects which may be interpreted along the same lines. The average number of students per classroom is not significant for academic achievement (only weakly significant in the case of the scores in mathematics). However, grouping the students by ability (into different classrooms or within the same classroom) has diverse effects. If they are grouped for all the subjects, the results are lower than if they are not grouped. If they are grouped only for some subjects, however, the achievement is better. Better results are also obtained when students with a native language different from the official one attend regular classes at the same time as receiving additional periods of instruction aimed at developing their skills in the official language. What is relevant here is that all the specific needs of the students can be attended to without losing the natural reference group of the students, their classroom. The same occurs when it comes to grouping students by ability. The best results are obtained when this grouping is only carried out for some specific subjects. 
The presence of full-time teachers is significant, preferably if they have a degree and the school provides them with effective resources for teaching. However, the correlation of these factors with the students' performance in the case of part-time teachers is either not significant or is only weakly significant. These data lead us to think that the presence of full-time teachers enhances a trust relationship with the students, close relations arising naturally. Moreover, a full-time contract allows the teacher to engage with the students in a deeper, more personal way.

In addition, the positive influence of an internal counsellor who is employed by the school (rather than an external service being contracted) supports the idea that personal interaction enhances career guidance.

As regards the use of digital devices, the results are inconsistent. This fact seems to suggest that it is not their use per se which is significant, but rather their role in the relationship experience.

It is notable that the existence of given programmes, policies and curricula per se does not guarantee a better performance, which reinforces the idea that all these structural aspects need to be implemented in conjunction with careful attention to personal relationships. This does not imply that suitable programmes, policies and curricula are not important, but rather that special attention should be paid to the way in which they are implemented in the classroom. For instance, we find that the existence of curricula related to multicultural topics (cultural diversity, perspectives on historical and social events, expression of diverse identities, planet conservation, equality between men and women or causes of poverty) does not bear upon academic results, while sharing experiences with people from other cultures (by means of exchange programmes with other countries, hosting foreign teachers or inviting external people to give lectures or seminars) does have a clear positive influence on results. In all cases, a personal face-to-face interaction, not by digital means, takes place. Another action which improves outcomes is that of generating living spaces for the students, such as bands, choirs, newspapers or magazines, or performances of plays or musicals, as well as providing the students with a room where they can do their homework.

Although it is surprising that not all extra-curricular collective activities bear positively upon academic achievement, it is not easy to say why some have a positive impact and others not. Perhaps it depends on the kind of relationships which the activities foster, although further research is needed to explore this issue.

Regarding the relationships with the families, there are two factors which weakly bear on academic results in a negative way, namely, whether the parents voluntarily participate in school activities or whether they take part in local school government. Another variable, whether or not the achievement data are communicated directly to the parents, has a significant negative influence on the students' academic performance. The only variable which has a positive influence on the students' achievement is the percentage of the parents who discuss their child's progress on the initiative of a teacher. These data may suggest that the relationships between teachers are parents are beneficial when they are oriented to cooperatively helping students during their learning process rather than merely giving the parents a "final sentence" on their child's achievement.

This kind of study should analyze not only the variables which bear upon academic achievement in a positive way, but also what correlates negatively or does not correlate at all with academic results. Observing what all these factors share, we suggest that decisions focused on a merely cognitive view or a desire to control the educational process hinder student performance. We find that the principals' day-to-day tasks usually address the legal and organizational dimensions in which the principal assumes the role of a manager trying to achieve certain standards of production and efficiency centered on skill acquisition [33]. In fact, the self concept of the principal as manager is what teaching staff typically criticize [34]. They tend to feel controlled by bureaucracy, which is behind the burn-out phenomenon [35]. Both the principals' behavior and the intentions behind them are decisive for both the relationships between principals and teaching staff and also 
between teachers and students. If these relationships are perceived as attempts of control it bears upon the educational process in a negative way [36].

It is surprising that the use which the school gives to the students' assessments or the inclusion of certain topics related to global competence in the curricula do not influence the academic performance, while other issues bear upon it in a negative way, such as grouping the students by ability in all subjects, a compulsory evaluation on the part of the students of both the teachers and the school, and using student achievements to evaluate the teachers or asking for external evaluations of the school performance. We can hypothesize that these actions are being experienced as control processes rather than as educational challenges aimed to enhance sustainable growth.

\section{Conclusions}

We have found that the attention to interpersonal relationships can be regarded as a common denominator in the organizational aspects of the schools which bear upon a sustainable achievement on the part of the students. This interpretation of the results leads us to recommend that principals of the schools make certain decisions related to the organizational aspects of the school. Dealing with personal and social aspects as a question of knowledge and working on socio-emotional skills is not sufficient for sustainable development to be enhanced. In particular, we find that the organizational aspects particularly relevant to global competence, such as working on critical thinking skills or the inclusion of multicultural aspects or topics such as climate change, global health or migration do not significantly bear upon student long-term achievement, while sharing face-to-face experiences with people from other cultures has a clearly beneficial impact. This finding indicates that personal and social issues should be dealt with in a living and experiential way.

In addition, other issues which reflect principals' way of understanding education, such as their visions of how to approach the career guidance of their students, the criteria for grouping students into different classes, or how the assessments of students and teachers are used, have a significant influence on students' long-term development, as is reflected in the PISA scores which have been analyzed. In particular, the results point to some decisions which the school principal could make in order to generate sustainable changes in their school, some of them not requiring more than an academic year to be implemented.

For instance, the specific needs of the students should be particularly attended to, but without their losing their natural reference group, their classroom. Student-student relationships should be enhanced also by the organization of collective activities, such as a play or a choir, which contribute to cooperation and trust. Moreover, in order to enhance teacher-students relationships, resources to employ full-time teachers should be allocated, preferably if these teachers have a degree and the school provides them with effective resources for teaching. In addition, it is beneficial to allocate specific resources for the employment of career guidance staff.

Regarding the relation of the school with the students' families, face-to-face interaction between teachers and parents should be promoted, but not at the moment of teachers communicating the students' achievement data, but rather during the process of learning, on the initiative of the teacher, with the goal of cooperatively helping the students' progress.

Finally, it is important that both teachers and students do not perceive the use of achievement data and students' feedback about teaching and school as an instrument of control, oriented to discover their weaknesses. Control of processes is necessary, but it should not ignore interpersonal relationships. A cooperatively designed process of evaluating and attending to teachers and students' needs, based on trust, offers a better option than that of appealing to the application of external control processes. The perspective of attending to personal relationships in education has also been considered in several educational treatises (which criticize an approach excessively centered on skills acquisition [16,37]) as well as in philosophical reflections [38], pedagogical discussions [39] and intervention proposals centered on interpersonal relationships [40-42]. 
Although only the influence of the organizational decisions on the marks in three disciplines has been analyzed, further indicators should be studied in order to establish clearly which organizational decisions foster a genuine personal and social growth. The students' assessment in global competence could be a way of evaluating the socio-personal growth of students in future editions of PISA, whenever the collected data are solid enough to be included in a serious study.

Author Contributions: Conceptualization, J.V.O.S. and I.L.; methodology: J.V.O.S. and E.A.-T.; formal analysis, E.A.-T. and C.G.-G.; investigation, E.A.-T., C.G.-G. and J.A.; resources, E.A.-T. and C.G.-G.; data curation, E.A.-T. and C.G.-G.; writing-original draft preparation, J.V.O.S. and I.L; writing—review and editing, I.L. and J.A.; visualization, J.A.; supervision, J.V.O.S. All authors have read and agreed to the published version of the manuscript.

Funding: This research was partially funded by ERASMUS+, 2018-1-ES01-KA203-050986. The APC was funded by UpToYou Education Fundation, Madrid Polytechnical University and ERASMUS+, 2018-1-ES01-KA203-050986.

Institutional Review Board Statement: Ethical review and approval were waived for this study, due to the data were directly obtained from PISA data base.

Informed Consent Statement: Informed consent was obtained from all subjects involved in the PISA study whose data have been used in this study.

Data Availability Statement: All the data which have been used can be found in OECD. PISA 2018 Data Base. Available online: https:/ / www.oecd.org/pisa/data/2018database/ (accessed on 30 June 2021).

Conflicts of Interest: The authors declare no conflict of interest.

\section{References}

1. UN General Assembly. Transforming Our World: The 2030 Agenda for Sustainable Development, 21 October 2015, A/RES/70/1. Available online: https:/ / www.refworld.org/docid/57b6e3e44.html (accessed on 1 July 2021).

2. Blazar, D.; Kraft, M.A. Teacher and teaching effects on students' attitudes and behavior. Educ. Eval. Policy Anal. 2017, 39, 146-170. [CrossRef]

3. Donaldson, M.L.; Woulfin, S. From tinkering to going "rogue": How principals use agency when enacting new teacher evaluation systems. Educ. Eval. Policy Anal. 2018, 40, 531-556. [CrossRef]

4. Jarl, M.; Andersson, K.; Blossing, U. Organizational characteristics of successful and failing schools: A theoretical framework for explaining variation in student achievement. Sch. Eff. Sch. Improv. Available online: https://www.tandfonline.com/doi/full/10 .1080/09243453.2021.1903941 (accessed on 24 March 2021).

5. Intxausti, N.; Joaristi, L.; Lizasoain, L. Educational leadership as best practice in highly effective schools in the Autonomous Region of the Basque Country (Spain). Educ. Manag. Adm. Leadersh. 2015, 44, 397-419. [CrossRef]

6. OECD Programme for International Student Assessment. PISA 2018 Global Competence. Available online: https: / www.oecd. org/pisa/innovation/global-competence/ (accessed on 1 July 2021).

7. OECD Teaching and Learning International Survey (TALIS). Questions Related to the Global Competence in the Student Questionnaire. Available online: https:/ /www.oecd.org/pisa/PISA-2018-Global-Competence-Questionnaire.pdf (accessed on 1 July 2021).

8. OECD Teaching and Learning International Survey (TALIS). Principal Questionnaire. Available online: https://www.oecd.org/ education/school/43081362.pdf (accessed on 1 July 2021).

9. Lundie, D. Authority, autonomy and automation: The irreducibility of pedagogy to information transactions. Stud. Philos. Educ. 2016, 35, 279-291. [CrossRef]

10. Giroux, H. Neoliberalism, youth and the leasing of higher education. In Global Liberalism and Education and Its Consequences; Hill, D., Kumar, R., Eds.; Routledge: New York, NY, USA, 2008; p. 24.

11. Sambell, K.; McDowell, L. The construction of the hidden curriculum: Messages and meanings in the assessment of student learning. Assess. Eval. High. Educ. 1998, 23, 391-402. [CrossRef]

12. Orón, J.V.; Akrivoú, K.; Escalzo, G. Educational Implications that arise from differing models of human development and their repercussions on social innovation. Front. Educ. 2019, 4, 139. [CrossRef]

13. Akrivoú, K.; Orón, J.V.; Escalzo, G. The Inter-Processual Self. Towards a Personalist Virtue Ethics Proposal for Human Agency; Cambridge Scholars Publising: Cambridge, UK, 2008.

14. Simkins, T. Leadership in education: 'What works or what makes sense'? Educ. Manag. Adm. Leadersh. 2005, 33, 9-26. [CrossRef]

15. Orón, J.V.; Scalzo, G.; Akrivou, K. Anthropological Foundations for Innovation in Organizations. Am. J. Manag. Dev. 2021, 21, 157-165. 
16. Semper, J.V.O.; Blasco, M. Revealing the hidden curriculum in higher education. Stud. Philos. Educ. 2018, 37, 481-498. [CrossRef]

17. Chetty, R.; Friedman, J.N.; Rockoff, J.E. Measuring the impacts of teachers I: Evaluation bias in teacher value-added estimates. Am. Econ. Rev. 2014, 104, 2593-2632. [CrossRef]

18. Scott, D.; Dweck, C. Mindsets that promote resilience: When students believe that personal characteristics can be developed. Educ. Psychol. 2012, 47, 302-314. [CrossRef]

19. OECD. PISA 2018 Data Base. Available online: https://www.oecd.org/pisa/data/2018database/ (accessed on 30 June 2021).

20. OECD 2019. PISA 2018 Assessment and Analytical Framework. Available online: https://www.oecd-ilibrary.org/docserver/85 0d0ef8-en.pdf?expires=1628509480\&id=id\&accname=guest\&checksum=D0104928ADF63F1EB9E141132EB576C4 (accessed on 9 August 2021).

21. Avvisati, F.; Le Donné, N.; Paccagnella, M. A meeting report: Cross-cultural comparability of questionnaire measures in large-scale international surveys. Meas. Instrum. Soc. Sci. 2019, 1, 8. [CrossRef]

22. Van de Vijver, F.; Avvisat, F.; Davidov, E.; Eidiv, M.; Foxv, J.-P.; Donné, N.L.; Lekv, K.; Meulemanv, B.; Paccagnella, M.; van de Schootvi, R. Invariance Analyses in Large-Scale Studies; OECD Education Working Papers; No. 201; OECD Publishing: Paris, France, 2019.

23. OECD. PISA 2018 Technical Report. Available online: https://www.oecd.org/pisa/data/pisa2018technicalreport/ (accessed on 30 June 2021).

24. Rozgonjuk, D.; Täht, K.; Vassil, K. Internet use at and outside of school in relation to low- and high-stakes mathematics test scores across 3 years. Int. J. STEM Educ. 2021, 8, 27.

25. Çoban, Ö. Relationships between Students' Socioeconomic Status, Parental Support, Students' Hindering, Teachers' Hindering and Students' Literacy Scores: PISA 2018. World J. Educ. 2020, 10, 45. [CrossRef]

26. Kraft, M.A. Interpreting effect sizes of education interventions. Educ. Res. 2020, 49, 241-253. [CrossRef]

27. Mckinsey Company. Reseña. Informe Mckinsey. 2011, pp. 89-92. Available online: https://studylib.es/doc/4741806/rese\%C3 \%B1a.-informe-mckinsey (accessed on 30 June 2021).

28. Smithers, L.G.; Sawyer, A.C.P.; Chittleborough, C.R.; Davies, N.M.; Davey, S.G.; Lynch, J.W. A systematic review and metaanalysis of effects of early life non-cognitive skills on academic, psychosocial, cognitive and health outcomes. Nat. Hum. Behav. 2018, 2, 867-880. [CrossRef] [PubMed]

29. Taylor, R.D.; Oberle, E.; Durlak, J.A.; Weissberg, R.P. Promoting Positive Youth Development through School-Based Social and Emotional Learning Interventions: A Meta-Analysis of Follow-Up Effects. Child Dev. 2017, 88, 1156-1171. [CrossRef]

30. MacCann, C.; Jiang, Y.; Brown, L.E.R.; Double, K.S.; Bucich, M.; Minbashian, A. Emotional intelligence predicts academic performance: A metaanalysis. Psychol. Bull. 2020, 146, 150-186. [CrossRef]

31. Wubbels, T.H.; den Brok, P.; van Tartwijk, J.; Levy, J. (Eds.) Interpersonal Relationships in Education. An Overview of Contemporary Research; Sense Publishers: Rotterdam, The Netherlands; Boston, MA, USA; Taipei, China, 2012.

32. Zandvliet, D.; den Brok, P.; Mainhard, T.; van Tartwijk, J. (Eds.) Interpersonal Relationships in Education. From Theory to Practice; Sense Publishers: Rotterdam, The Netherlands; Boston, MA, USA; Taipei, China, 2014.

33. Agudo, J.L.B. Funciones de los directores escolares una nueva función pública hacia el gerencialismo. Forum Aragón Rev. Digit. FEAE-Aragón Sobre Organ. Gestión Educ. 2014, 12, 18-26.

34. Rodriguez, F.M.G. La mirada de los otros. El director escolar visto por el profesorado. Aula Abierta 2006, 88, 151-178.

35. Rodríguez, J.A.; Guevara, A.; Viramontes, E. Síndrome de burnout en docentes. IE Rev. de Investig. Educ. REDIECH 2017, 8, 45-67. [CrossRef]

36. Blase, J. Some Negative Effects of Principals' Control-Oriented and Protective Political Behavior. Am. Educ. Res. J. 1990, 27, 727-753. [CrossRef]

37. Irena, P. Between Rationality and Emancipation: (De)Constructing Competency-Based Education. In W: A. Stopińska-Pajak (Red.), "Between History and the Theory of Education: Methodology, Traditions, Quest" (S. 111-130); Wydawnictwo Uniwersytetu Ślaskiego: Katowice, Poland, 2015.

38. Biesta, G. Beyond Learning: Democratic Education for a Human Future; Paradigm: Boulder, CO, USA, 2006.

39. Robinson, S. Connections-Based Learning. A Framework for Teaching and Learning in a Connected World; Connections-Based Learning: Port Coquitlam, BC, Canada, 2017.

40. Anson, A.; Cook, T.D.; Habib, F.; Grady, M.K.; Haynes, N.; Comer, J.P. The Comer School Development Program: A Theoretical Analysis. Urban Educ. 1991, 26, 56-82. [CrossRef]

41. Orón, J.V. Encuentro Interprocesual. Por un Mundo Para el Crecimiento Interpersonal; ICCE: Madrid, Spain, 2020; ISBN 978-84-121543-1-3.

42. Orón, J.V. Nueva propuesta de educación emocional en clave de integración y al servicio del crecimiento. Metafísica Pers. 2016, 16, 91-152, ISSN digital: 1989-4996. 